\title{
TEXTUAL CONVENTIONS
}

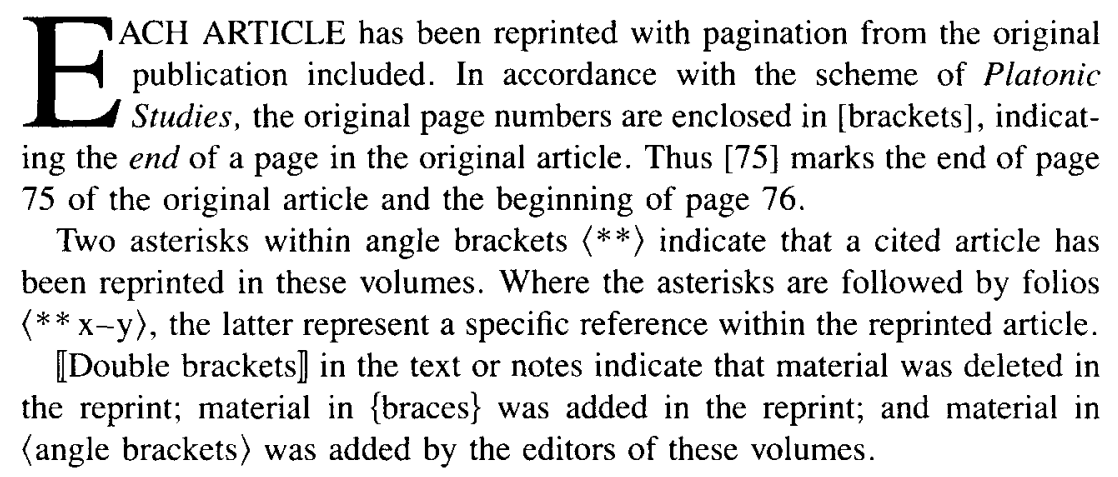


